\title{
Improvement Salt Tolerance of Safflower Plants by Endophytic Bacteria
}

\author{
Khaulood A. Hemida ${ }^{1 *}$, Amany M.M. Reyad ${ }^{1}$ \\ ${ }^{1}$ Botany Department, Faculty of Science, Fayoum University, Fayoum, Egypt \\ kah00@Fayoum.edu.eg, khulod_hemida@yahoo.com
}

Keywords: Endophytic bacteria, ACC deaminase activity, Salt stress alleviation

\begin{abstract}
Salinity is one of the most dangerous environmental limiting factors of the plant productivity. A wide range of adaptation strategies is required to overcome salinity stress. However, such strategies seem to be long drawn and cost-intensive. It has been confirmed in recent years that plant growth promotes endophytes (PGPEs) that have the ability to further build a symbiotic association with their host to improve host plant salt tolerance. In our investigation the main goal is to improve plant salt tolerance using different species of endophytic bacteria. From the total eight endophytic bacterial species that were isolated from root, stem, and leaf of Carthamus tinctorius (safflower) plant, two isolates were capable of using 1-aminocyclopropane-1-carboxylic acid (ACC) as a sole nitrogen source, and they are of positive results for (ACC) deaminase activity and indole-3-acetic acid (IAA) production. This study showed that the bacterial strains $B$. cereus and $B$. aerius are valuable biological plant growth promoters that could enhance salt tolerance in Safflower plants under 100,200 , and $300 \mathrm{mMNaCl}$ levels resulting in an increase in plant growth and ascorbate-glutathione redox cycle, in comparison with the non-inoculated controls. Our findings reported that the co-inoculation of the two selected endophytic bacteria strains were successfully isolated from Safflower seedlings significantly alleviated the harmful effects of salt stress and promoted plant growth and biomass yield.
\end{abstract}

\section{Introduction}

Plant growth promoting bacteria (PGPB) comprise a group of beneficial bacteria that can be found in the rhizosphere, or the inside of plant tissues as endophytes [1]. The role of microorganisms in plant growth promotion is well established and well known; these beneficial microorganisms colonize the endo-rhizosphere/rhizosphere of plants and promote the growth of the plants through various direct and indirect mechanisms [2-3]. PGPB are able to promote plant growth via direct or indirect mechanisms, or a combination of both. Indirect mechanisms include the suppression of pathogens through production of antibiotics and extracellular hydrolytic enzymes [4]. Direct mechanisms include an altered nutrition through the provision of fixed nitrogen; iron through siderophores; soluble phosphate (P) and zinc ( $\mathrm{Zn})$ [5-6]. The Production of phytohormones takes place through indole acetic acid, cytokinin, and gibberellins [7-8] or by the activity of 1aminocyclopropane-1-carboxylic acid (ACC) deaminase [9]. In the last decade, different bacterial genera belonging to Bacillus, Rhizobium, Pseudomonas, Burkholderia, Paenibacillus, Achromobacter, Microbacterium, Azospirillum, Enterobacter, Variovorax, Methylobacterium etc. have been reported to promote host plants under different abiotic stress environments [10].

It was accompanied that salt stress is one of the major abiotic stress factors that alter physiology and biochemistry of plant, causing a reduction in crop productivity [11]. Crop productivity is affected by salinity. This is because most of the crops are salt sensitive. Needs for adaptations are essential to defeating salinity stress. Because the strategies developed are long drawn and exhaustive, there is a requirement to obtain biological methods to overcome salt stress. [12]; therefore, microorganisms could play an important role in this respect by the production of plant growth promoting hormones, synthesis of compatible solutes, and genetic diversity. Also, it was accomplished that salt tolerance is a complex feature which comprises numerous genes and various physiological and biochemical mechanisms [13]. The production of ethylene enhanced by salt stress in plants leads to premature death of these plants [14]. 
ACC deaminase is an enzyme that can lower plant ethylene levels that are increased by a variety of environmental stresses, such as flooding, drought, heavy metals, organic contaminants, and salt stress. ACC deaminase activity is an efficient marker for bacteria to promote plant growth by lowering ethylene levels in plants [15]. ACC deaminase activity has long been a key marker for identifying the plant growth-promoting bacteria [16]. Bacteria containing ACC deaminase can down-regulate the plant genes involved in ethylene-induced stress responses and defense signaling pathways [17]. Plants that are treated with ACC deaminase-containing PGPB are dramatically more resistant to the effects of stress ethylene that is synthesized as a consequence of stressful conditions such as drought and high salt [18]. In each of these cases, the ACC deaminase-containing plant growth promoting bacteria markedly lowered the level of ACC in the stressed plants thereby limiting the amount of stress ethylene synthesis and; hence, the damage to the plant. Therefore, the aim of this study was to evaluate the potential increase of salt tolerance in Safflower seedlings by using plant growth promoting endophytes (PGPEs); bacterial strains B. cereus and B. aerius, used as seed soaking. Seedling growth, low molecular weight antioxidants and enzymatic antioxidants were assessed to see whether these parameters were improved, by using this technique, to support the antioxidative defense system of Safflower seedlings to increase their salt tolerance.

\section{Materials and Methods}

\subsection{Plant material and growing conditions}

It was identified that oxidative stress is initiated by reactive oxygen species (ROS), which are produced and fairly accumulated during normal aerobic metabolism. Failure to quench or inactivate the ROS may lead to the degradation of macro molecules in the plant cells such as membrane lipids, proteins and nucleic acids [19]. Referring to $\mathrm{H}_{2} \mathrm{O}_{2}$ production it may be the main symptomatic parameters for oxidative stress developed in response to high salinity. Due to the imbalance in ROS production and antioxidant activity, $\mathrm{H}_{2} \mathrm{O}_{2}$ level increases with increasing salinity in different plants [20]. A battery of ant-ioxidative mechanisms was found in plant to scavenge the ROS, which include non-enzymatic antioxidants like ascorbic acid (AsA), reduced glutathione (GSH), $\alpha$ tocopherol (TOC) and carotenoids, and enzymatic antioxidants such as superoxide dismutase(SOD), ascorbate peroxidase (APX), catalase (CAT), glutathione reductase (GR) [21-22]. Plants are found to synthesize low molecular weight antioxidants such as glutathione and ascorbate within the chloroplast stroma and cytosol using nicotinamide adenine dinucleotide phosphate (NADPH) as the ultimate electron donor [23]. These low molecular weight antioxidants are functioned to do as redox buffers that interact with numerous cellular components and influence plant growth and development by modulating processes from mitosis and cell elongation to senescence and death [19]. In addition, these antioxidants may influence gene expression associated with biotic and abiotic stress responses to maximize defense of stressed plants.

\subsection{Isolation of salt tolerant entophytic bacteria from Safflower plant parts}

Roots, stems, and leaves were washed with tap water followed by distilled water to remove the soil particles then, were excised and subjected to three steps of surface sterilization procedure according to [24] Step 1: plant parts were washed with 70\% ethanol for 1 min and subsequently were washed with sterilized distilled water. Step 2: They were soaked in $0.1 \%$ mercuric chloride for 3 min and were washed with distilled water for 2 times. Step 3: They were soaked in $70 \%$ ethanol for $30 \mathrm{~s}$ and washed for 5 to 7 times with distilled water. The surface sterilized plant parts were aseptically sectioned into small pieces $(0.1 \mathrm{~cm}$ thickness $)$. The sections were made and placed on to the plates containing isolation medium (Nutrient agar) supplemented with $\mathrm{NaCl}(0,100,300,600$, 900 and $1200 \mathrm{mM} \mathrm{NaCl}$ ) was added in nutrient agar as a basal medium during incubation at $28^{\circ} \mathrm{C}$ for $48 \mathrm{hrs}$ [25]. The bacterial growth associated with plant sections were purified by repeated plating on saline nutrient agar. Bacterial isolates were selected based on colony morphology and growth rate. To confirm that these isolates are endophytic, $1 \mathrm{~mL}$ aliquots of the sterilized distilled water that was used in the final rinse of surface sterilization procedures were plated onto NA 
medium as a control. Pure cultures of the halotolerant bacterial isolates were maintained in $30 \%$ glycerol at $-80^{\circ} \mathrm{C}$.

\subsection{Detection of the bacterial growth in liquid medium supplemented with serial $\mathrm{NaCl}$ levels}

Experiments aiming to study the effect of different concentrations of $\mathrm{NaCl}$ on the growth of the bacterial isolates were conducted in $250 \mathrm{~mL}$ flask containing $50 \mathrm{~mL}$ The mineral salt medium $(\mathrm{MSM})$ of glucose $(2 \mathrm{~g} / \mathrm{L}), \mathrm{K}_{2} \mathrm{HPO}_{4}(0.4 \mathrm{~g} / \mathrm{L}), \mathrm{KH}_{2} \mathrm{PO}_{4}(0.2 \mathrm{~g} / \mathrm{L}), \mathrm{NaCl},(0.1 \mathrm{~g} / \mathrm{L}), \mathrm{MgSO}_{4} .7 \mathrm{H}_{2} \mathrm{O}$ $(0.5 \mathrm{~g} / \mathrm{L}), \mathrm{MnCl}_{2}(0.01 \mathrm{~g} / \mathrm{L}), \mathrm{Fe}_{2}\left(\mathrm{SO}_{4}\right)_{3}(0.01 \mathrm{~g} / \mathrm{L}), \mathrm{Na}_{2} \mathrm{MoO}_{4}(0.01 \mathrm{~g} / \mathrm{L})$ and $1 \mathrm{~mL}$ trace element solution per liter [26] supplemented with different concentrations of $0,100,300,600,900$ and $1200 \mathrm{mM} \mathrm{NaCl}$. The medium was inoculated by five milliliters of bacterial cell suspension $\left(\mathrm{OD}_{600}=0.1\right)$ and incubated on a rotary shaker $(120 \mathrm{x} \mathrm{g})$ at $28^{\circ} \mathrm{C}$ for $48 \mathrm{hrs}$. Cell growth in liquid media was determined spectrophotometrically by measuring the cultural optical density at $600 \mathrm{~nm}$ $\left(\mathrm{OD}_{600}\right)$. The protein content of the bacterial cultures was assayed using Bradford assay (Bradford, 1976) in order to confirm the bacterial growth.

\subsection{Determination of IAA production of bacterial halotolerant}

Salkowski's colorimetric method was used to determine the IAA production ability by each isolate. The pure culture of each isolate was grown in a nutrient broth medium containing $0.1 \mathrm{mg} / \mathrm{ml}$ 1-tryptophan and $5 \% \mathrm{NaCl}$ and was incubated at $30^{\circ} \mathrm{C}$ for 2 days. After incubation, the broth was centrifuged, the supernatant was retained and $1 \mathrm{~mL}$ of supernatant was mixed with $2 \mathrm{~mL}$ of Salkowski's reagent $\left(2 \% 0.5 \mathrm{FeCl}_{3}\right.$ in $35 \% \mathrm{HClO}_{4}$ solution) and kept in the dark for minimum $30 \mathrm{~min}$. Subsequently, the optical density (OD) was measured at $530 \mathrm{~nm}$.

\subsection{Selection of bacterial isolates that contain ACC deaminase}

Dilutions of this final salt tolerant culture are plated onto solid DF-ACC medium DF (containing $4 \mathrm{~g} \mathrm{KH}_{2} \mathrm{PO}_{4}, 6 \mathrm{~g} \mathrm{Na}_{2} \mathrm{HPO}_{4}, 0.2 \mathrm{~g} \mathrm{MgSO}$, $1 \mu \mathrm{g} \mathrm{FeSO}_{4}, 10 \mu . \mathrm{g} \mathrm{H} \mathrm{BO}_{3}, 10 \mu \mathrm{g} \mathrm{MnSO}_{4}$, $70 \mu \mathrm{g} \mathrm{ZnSO}_{4}, 50 \mu \mathrm{g} \mathrm{CuSO}_{4}$ and $10 \mu \mathrm{g} \mathrm{MoO}_{3}$ with $0.2 \%$ glucose, $0.2 \%$ gluconic acid and $0.2 \%$ citric acid/litter) supplemented with $0.3 \mathrm{mM}$ ACC as a sole nitrogen source. The DF medium was prepared as described by [27] and then incubated for $72 \mathrm{~h}$ at either 25 or $28^{\circ} \mathrm{C}$. The inoculated plates are incubated for 3 days at the appropriate temperature no higher than $35^{\circ} \mathrm{C}$ because all of the known ACC deaminases are inhibited above this temperature and the growth on the plates is checked daily. Even when apparently nitrogen-free agar is used, and no additional source of nitrogen is included in the medium, it is almost impossible to obtain plates with absolutely no bacterial growth but it is possible to get plates with very, very light growth. A solution of ACC was filter-sterilized through the $0.2 \mu \mathrm{m}$ membrane and frozen at $-20^{\circ} \mathrm{C}$. Just prior to use, the frozen ACC solution was thawed and added into autoclaved DF minimal medium to obtain the DF-ACC medium with a final ACC concentration of $3 \mathrm{mM}$. Solid DF and DF-ACC media were supplemented with $1.5 \%(\mathrm{w} / \mathrm{v})$ ultrapure agar [28].

\subsection{Identification of the bacterial isolates}

For identification of the isolated bacteria, the genomic DNA was extracted using standard bacterial procedures [29]. The primers used in the amplification of the 16S rDNA gene are forward primer (F1; AGA GTT TGA TCC TGG CTC AG) and reverse primer (R1; GGT TAC CTT GTT ACG ACT T). The PCR mixture was prepared as the following; $10 \mu \mathrm{L}$ (10x) PCR buffer, $3 \mu \mathrm{L}(50$ $\mathrm{mM}) \mathrm{MgCl}_{2}, 1 \mu \mathrm{L}(20 \mathrm{pmole} / \mu \mathrm{L})$ of each primer, $1 \mu \mathrm{L}(10 \mathrm{mM}) \mathrm{dNTPs}$ mixture, $0.5 \mu \mathrm{L}(2.5 \mathrm{U}) \mathrm{Taq}$ DNA polymerase, $2 \mu \mathrm{L}$ total DNA extract, and the volume is completed to $100 \mu \mathrm{L}$ by $\mathrm{SDH}_{2} \mathrm{O}$. PCR were carried out for 35 cycles under the following conditions: denaturation step at $94^{\circ} \mathrm{C}$ for $40 \mathrm{sec}$, annealing step at $55^{\circ} \mathrm{C}$ for $1 \mathrm{~min}$, extension step at $72^{\circ} \mathrm{C}$ for $2 \mathrm{~min}$ and final extension at $72^{\circ} \mathrm{C}$ for $10 \mathrm{~min}$. An aliquot of the PCR products $(10 \mu \mathrm{L})$ was mixed with $2 \mu \mathrm{L}$ of DNA loading buffer and analyzed by electrophoresis $(15 \mathrm{~V} / \mathrm{cm}, 60 \mathrm{~min})$ on $0.7 \%$ horizontal agarose gel in TBE buffer containing $0.5 \mu \mathrm{g} / \mathrm{mL}$ ethidium bromide, then visualized on an UV transilluminator. Sequencing of the amplified fragments was performed at GATC Biotech, Constance, Germany. DNA Sequences were aligned at NCBI Data Base (www.ncbi.nlm.nlh.gov). Phylogenetic trees were established 
using neighbor-joining technique using TREEVIEW software (1.6.6) derived from 16S rRNA gene sequences of some strains phylogenetically close to the isolated strain. Both sequences had accession numbers by their submission in GenBank NCBI database.

\subsection{ACC deaminase activity}

The activity was analyzed according to a colorimetric 2, 4 - dinitrophenyl-hydrazine assay of the product a-ketobutyrate as described by $[30,26]$. The activity was also measured as described by [31] by measuring the consumption of the substrate ACC after 24-h growth in a minimal medium with an initial ACC concentration of $3 \mathrm{mM}$. To prepare ninhydrin reagent, five hundred milligrams of ninhydrin and $15 \mathrm{mg}$ of ascorbic acid were dissolved in $60 \mathrm{~mL}$ of ethylene glycol, stored at $-20^{\circ} \mathrm{C}$ and mixed with $60 \mathrm{ml}$ of $1 \mathrm{mM}$ citrate buffer ( $\mathrm{pH} \mathrm{6.0)}$ ) prior to use. Standard colorimetric ninhydrin assay of ACC with test tubes and cuvettes The DF-ACC medium (with an ACC concentration of $3 \mathrm{mM}$ ) was diluted with the DF medium to respective ACC working concentrations of $0.005,0.01$, $0.015,0.02,0.03,0.04,0.05,0.10,0.15,0.20,0.25,0.30,0.40$ and $0.50 \mathrm{mM})$. After the addition of $1 \mathrm{~mL}$ of ACC working solution and $2 \mathrm{~mL}$ of ninhydrin reagent, glass test tubes were capped and shaken and placed in a boiling water bath. After $15 \mathrm{~min}$, the tubes were moved into a water bath at room temperature for $2 \mathrm{~min}$ and then shaken for $30 \mathrm{~s}$. After standing at room temperature for $10 \mathrm{~min}$, the solution was transferred into a cuvette and absorbance was measured at $570 \mathrm{~nm}$ with a spectrophotometer. The DF medium was used as a blank. Each working solution was run in triplicate. In addition, $1 \mathrm{ml}$ of a tenfold diluted supernatant of a bacterial culture was used to determine ACC in bacterial cultures with the standard ninhydrin assay.

\subsection{Seed treatment and gnotobiotic growth pot assays}

Seed treatment was performed in accordance with [26] with slight modifications. Briefly, halotolerant bacterial isolates were grown in nutrient broth supplemented with $500 \mathrm{mM} \mathrm{NaCl}$. The cells were then collected and re-suspended in an N-free medium supplemented with $3 \mathrm{mM}$ ACC as the sole nitrogen source, and subsequently incubated for $24 \mathrm{~h}$ at $30^{\circ} \mathrm{C}$ with shaking $(120 \mathrm{x} \mathrm{g})$ in order to induce ACC deaminase activity. After that, the cells were harvested and washed by resuspension in sterile $0.03 \mathrm{M} \mathrm{MgSO}_{4}$. Safflower seeds (from Agriculture Research Center., Giza., Egypt) were surface sterilized by immersion in $70 \%$ ethanol for $1 \mathrm{~min}$ and $2 \% \mathrm{NaOCl}$ for $30 \mathrm{~s}$ followed by a thorough rinsing in sterilized distilled water (3-4 times). Then, these surfacesterilized seeds were soaked in sterilized $(0,100,200$ and $300 \mathrm{mM} \mathrm{NaCl})$, or soaked in the solution containing $\mathrm{NaCl}(0,100,200$ and $300 \mathrm{mM})$ and bacterial culture of $\left(5 \times 10^{8} \mathrm{CFU} / \mathrm{mL}\right)$ for $24 \mathrm{~h}$. Surface sterilized soaked seeds were transferred aseptically to previously sterilized seed germination pots (soil was previously autoclaved at $121^{\circ} \mathrm{C}$ for $20 \mathrm{~min}$ ). Ten seeds were placed in each pot for each treatment and each treatment with five replicates.

\subsection{Estimation of ascorbic acid content}

It was quantified according to the method of [32].

\subsection{Estimation of glutathione (GSH) content}

Reduced glutathione was determined by the method of [33].

\subsection{Antioxidant enzymatic activities}

Plant cells were homogenized [34] in a cold mortar with $4 \mathrm{~mL} 100 \mathrm{mM}$ phosphate buffer $(\mathrm{pH}$ 7.2) containing $60 \mathrm{mM} \mathrm{KH}_{2} \mathrm{PO}_{4}, 40 \mathrm{mM} \mathrm{K}_{2} \mathrm{HPO}_{4}, 0.1 \mathrm{mM}$ DTPA and $1 \%(\mathrm{w} / \mathrm{v})$ PVPP. The homogenate was centrifuged at $18.000 \mathrm{x}$ g for $10 \mathrm{~min}$ at $4^{\circ} \mathrm{C}$ and the supernatant was used for enzyme activity determination.

\subsection{The catalase (CAT) activity}

The CAT activity was measured as described previously by [35]. 


\subsection{The ascorbate peroxidase (APX) activity}

The APX activity was measured in a $1 \mathrm{~mL}$ reaction volume containing $80 \mathrm{mM}$ potassium phosphate buffer (pH 7.0) as described by [36].

\subsection{The glutathione reductase (GR) activity}

The GR was estimated by measuring the decrease of absorbance at $340 \mathrm{~nm}$ due to the oxidation of NADPH by the method described by [37].

\subsection{Statistical analysis}

Analysis of variance was performed using standard techniques and differences between the means were compared through Duncan multiple range test $(\mathrm{P}<0.05)$.

\section{Results}

\subsection{Isolation salt tolerant endophytic bacteria}

Eight salt tolerant endophytic bacterial isolates from safflower root, stem, and leaf were isolated after $24 \mathrm{hrs}$. Incubation of previously surface sterilized Safflower plant parts. Bacterial colonies were found emerging from the ends of plant parts on nutrient agar medium supplemented with gradient $\mathrm{NaCl}$ concentrations $(100,300,600,900$ and $1200 \mathrm{Mm})$. Three bacterial isolates from leaf (designated as LB1, LB2, and LB3), three from the stem (designated as SB1, SB2, and SB3), and two from the root (designated as RB1 and RB2) were obtained, but their salt tolerance was variable from one to another. LB1, SB1, and RB1 tolerated till $1200 \mathrm{mM} \mathrm{NaCl}, \mathrm{LB} 2$ isolate began to be inhibited at $600 \mathrm{mM} \mathrm{NaCl}$ and the other isolates were inhibited at $900 \mathrm{mM}$ and $1200 \mathrm{mM} \mathrm{NaCl}$. The growth was detected on growth plates of solidified nutrient agar plus $\mathrm{NaCl}$ gradient concentrations.

\subsection{Effect of different $\mathrm{NaCl}$ concentrations on bacterial growth}

In order to detect the effect of $\mathrm{NaCl}$ concentrations on bacterial growth, optical density and protein content were measured. Fig $1 \& 2$ showed that SB1, LB1, and RB1 tolerated to high salt concentration $(1200 \mathrm{mM})$. The maximum optical density $(0.91)$ was recorded at normal growth conditions for SB1 and protein content $412.9 \mathrm{mg} / \mathrm{L}$.

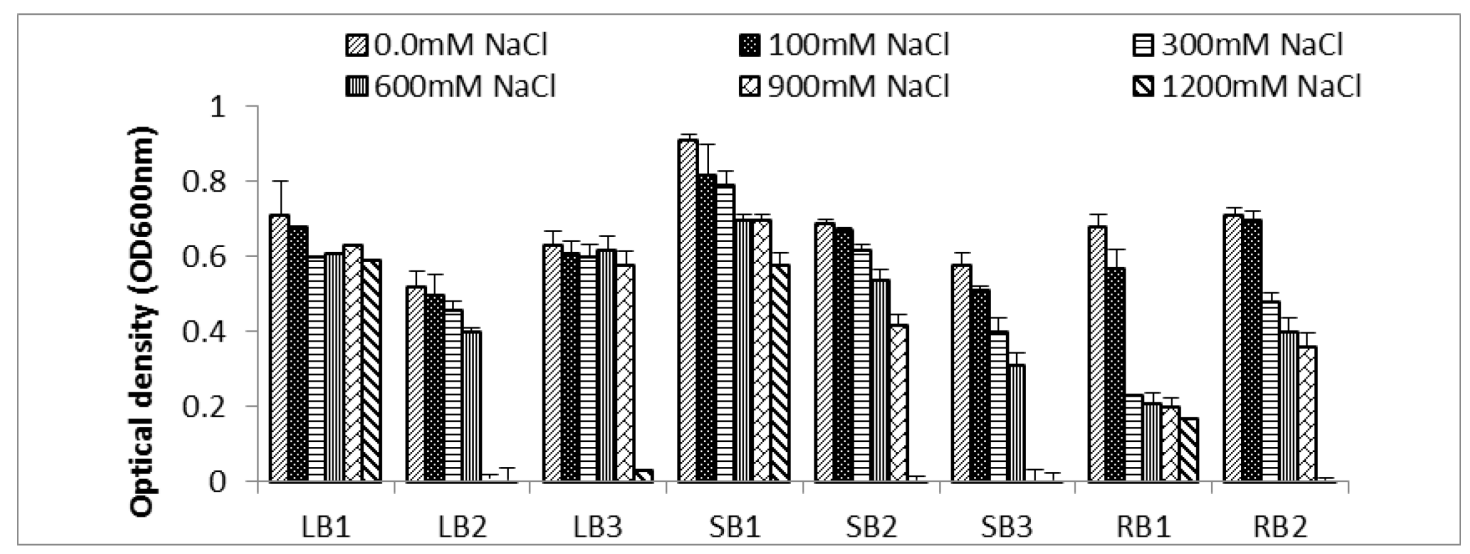

Figure 1. The effect of different salt levels on the bacterial growth in terms of optical density $\left(\mathrm{OD}_{600 \mathrm{~nm}}\right)$ after $48 \mathrm{hrs}$ growth. Data represent the mean of three replicates $\pm \mathrm{SE}$. 


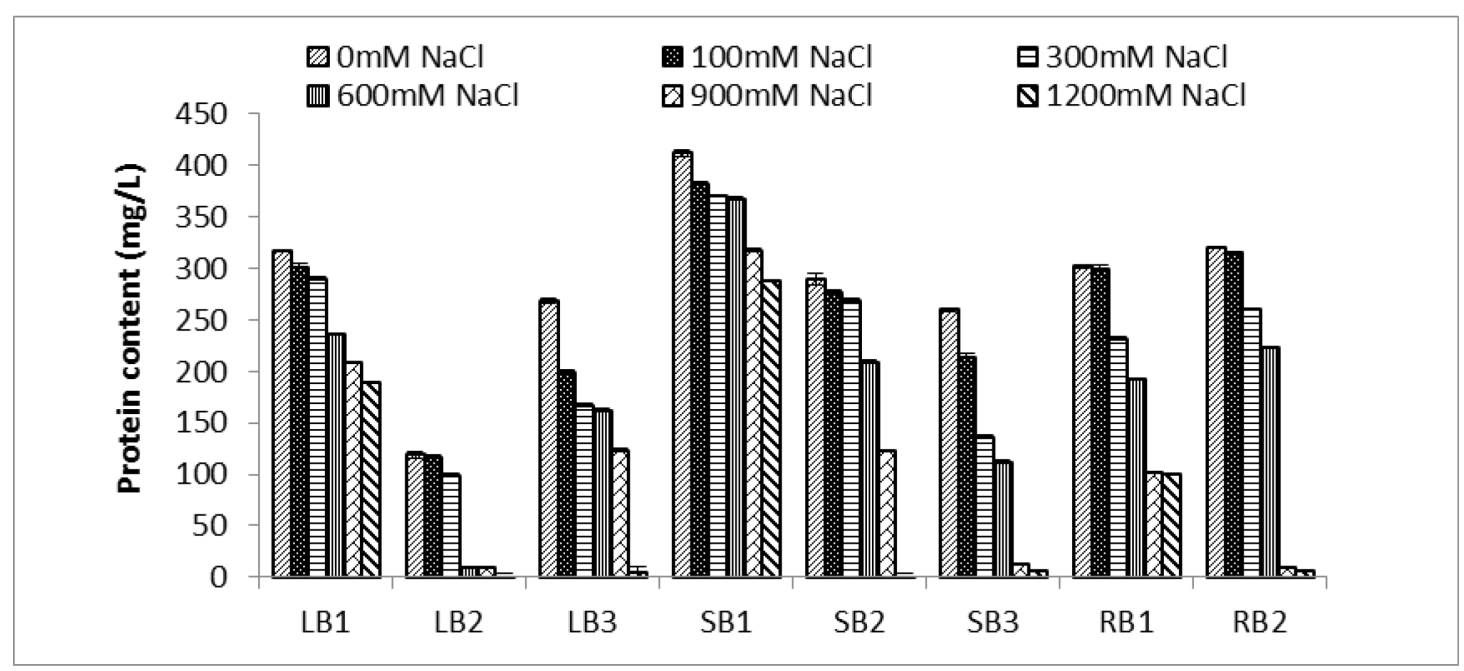

Figure 2. The effect of different salt levels on the bacterial growth in terms of protein content $(\mathrm{mg} / \mathrm{L})$ after $48 \mathrm{hrs}$ growth. Data represent the mean of three replicates $\pm \mathrm{SE}$.

\subsection{Selection bacterial isolates of ACC utilization}

Table (1) showed that two bacterial isolates from the eight salt tolerant ones could use ACC as a sole nitrogen source; these two were related to Safflower stem and leaf. This selection was made using minimum salt medium and DF medium supplemented ACC as a sole nitrogen source. Based on growth degree of bacterial isolates on plates, a comparison the growth of bacterial isolates with control (growth medium devoid of nitrogen source) that appeared very light growth on plates was made. Two bacterial isolates have grown densely on growth plates compared to other six ones that gave light growth as a control. This test is considered as a preliminary test which indicated that these two bacterial isolates could have ACC deaminase activity.

Table 1. Determination the ability of the eight endophytic bacterial isolates to produce IAA and utilize ACC as a sole nitrogen source.

\begin{tabular}{|l|l|l|l|}
\hline $\begin{array}{c}\text { Bacterial } \\
\text { isolate }\end{array}$ & \multicolumn{1}{|c|}{ Tissue } & \multicolumn{1}{c|}{$\begin{array}{c}\text { IAA production (mg/ml } \\
\text { bacterial culture) }\end{array}$} & \multicolumn{1}{|c|}{ ACC utilization } \\
\hline LB1 & Safflower leaf & + ve $(66 \pm 0.97)$ & +ve(dense growth) \\
\hline LB2 & Safflower leaf & -ve & -ve(light growth) \\
\hline LB3 & Safflower leaf & + ve $(33 \pm 0.89)$ & -ve(light growth) \\
\hline SB1 & Safflower stem & + ve $(73 \pm 2.15)$ & +ve(dense growth) \\
\hline SB2 & Safflower stem & -ve & -ve(light growth $)$ \\
\hline SB3 & Safflower stem & + ve $(56 \pm 1.21)$ & -ve(light growth) \\
\hline R1 & Safflower root & + ve $(47 \pm 0.97)$ & -ve(light growth) \\
\hline R2 & Safflower root & + ve $(31 \pm 0.64)$ & -ve(light growth $)$ \\
\hline
\end{tabular}

Each value represents mean $\pm \mathrm{SE}$ of three replicated experiment

\subsection{IAA production test}

All isolates were tested for IAA production as an effective property of the bacteria to promote plant growth under normal and saline conditions. Six of them could produce IAA (Table 1) and the other two isolates (SB2 and LB2) could not produce IAA and gave negative results. 


\subsection{Identification of endophytic LB Iand SB1 bacterial isolates}

The LB1and SB1 isolates were identified as Bacillus cereus and Bacillus aerius using 16S rDNA gene sequencing technique. The phylogenetic tree of the growth-promoting bacterial strain LB1 and related bacterial species based on the $16 \mathrm{~S}$ rDNA sequence was provided in Fig. 3. It can clearly be seen that the LB1 bacteria were included in the genus Bacillus and closely related to the species cereus. It showed the highest sequence similarities with Bacillus cereus ATCC strain. The strain sequence was submitted to GenBank and had accession number MG708176.

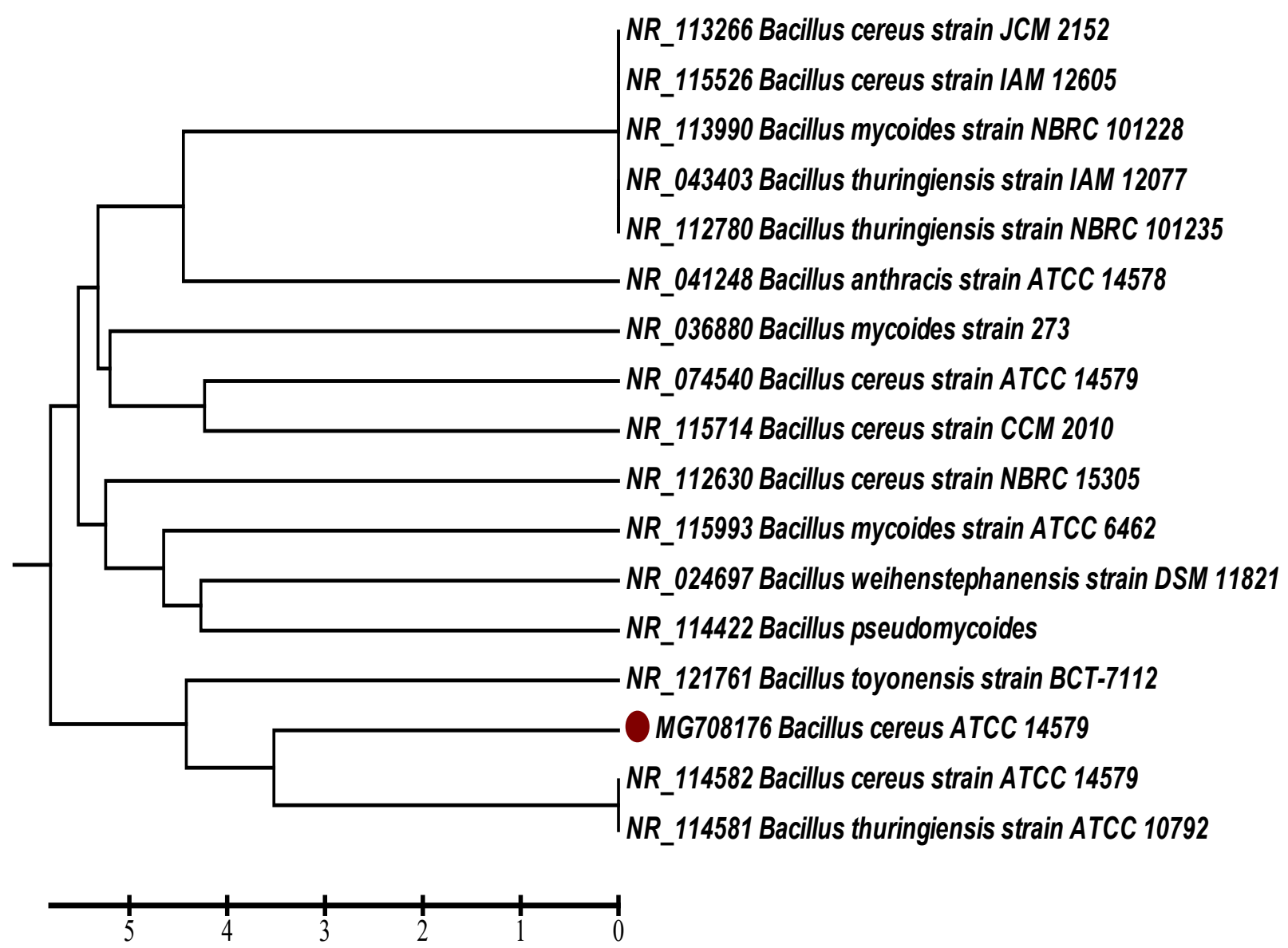

Figure 3. Phylogenetic dendrogram obtained by distance matrix analysis of $16 \mathrm{~S}$ rDNA sequences, showing the position of LB among phylogenetic neighbors. The red bullet indicates the position of LB strain.

The phylogenetic tree of the growth-promoting bacterial strain SB1 and related bacterial species based on the 16S rDNA sequence were provided in Fig. 4. It can clearly be seen that the SB1 bacteria were included in the genus Bacillus and closely related to the species aerius. It showed the highest sequence similarities with Bacillus aerius strain $24 \mathrm{~K}$ strain. The strain sequence was submitted to GenBank and had accession number MG711593. 


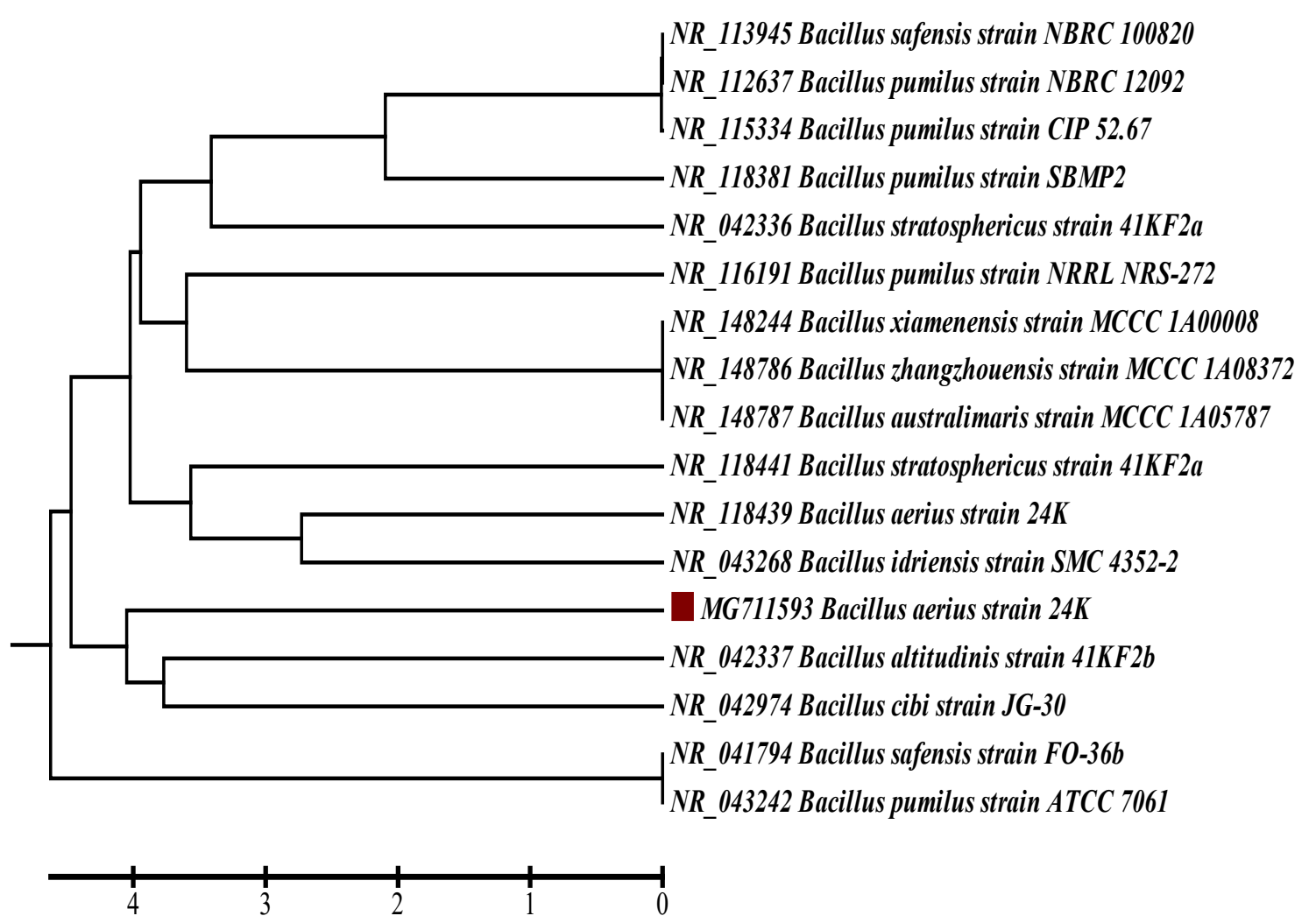

Figure 4. Phylogenetic dendrogram obtained by distance matrix analysis of 16S rDNA sequences, showing the position of SB strain among phylogenetic neighbors. The red bullet indicates the position of SB1 strain.

\subsection{ACC determination by colorimetric ninhydrin assay}

Two bacterial isolates could use ACC as a sole nitrogen source. Test for ACC utilization was made via colorimetric ninhydrin assay that ethylene glycol used as the solvent stabilizer and ascorbic acid in the ninhydrin reagent prevented the ninhydrin from oxidation. The absorbance values of the most salt tolerant safflower endophytic bacterial isolates of ACC utilization were significantly lower than that of the diluted non-inoculated DF-ACC medium. Bacillus cereus and Bacillus aerius consumed nearly all the $3 \mathrm{mM}$ of ACC in the DF-ACC medium after the24-h incubation (Fig. 5). Consequently, the color depth of the two bacterial cultures was visibly weaker compared with that of the non-inoculated DF-ACC medium.

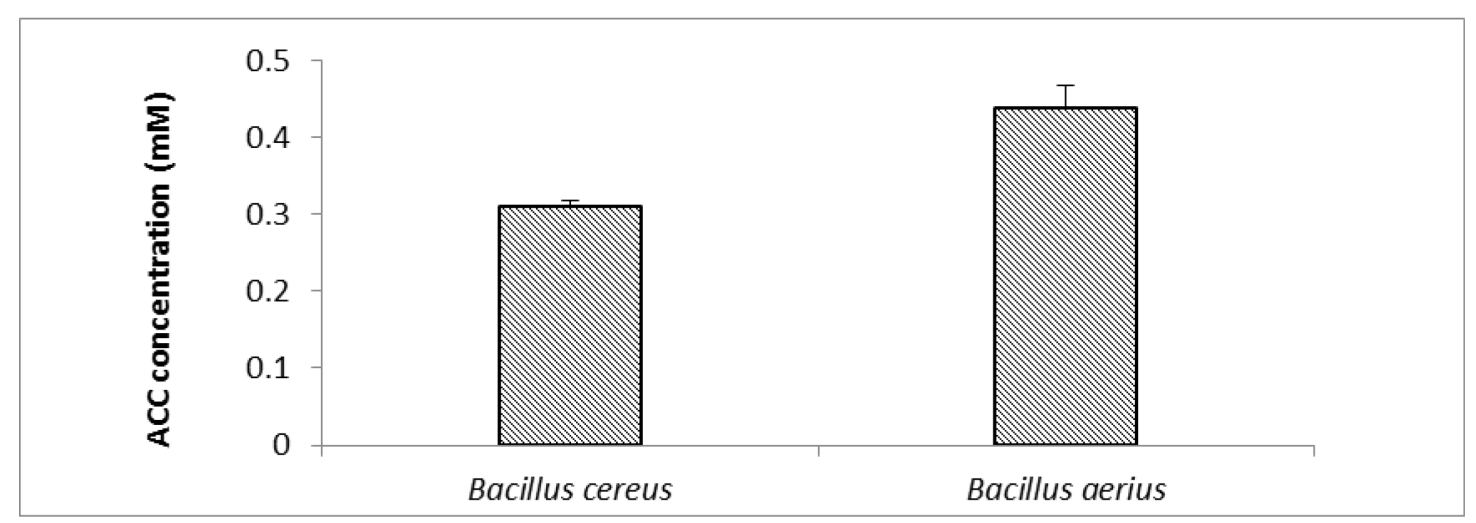

Figure 5. ACC concentrations remaining in the DF-ACC medium containing $3.0 \mathrm{mM}$ ACC after incubation of each ACC-utilizing bacterial isolate $24 \mathrm{~h}$ measured by the test tubes ninhydrin assay. Each data point represents the mean from triplicate determinations, and the error bar represents the standard error. 


\subsection{ACC deaminase activities of ACC-utilizing bacteria}

ACC deaminase activity for the two ACC-utilizing bacterial isolates (Fig. 6) used by the colorimetric 2, 4-dinitrophenylhydrazine assay represented that Bacillus cereus gave high $\mu \mathrm{mol}$ $\alpha$-KB h${ }^{-1} \mathrm{mg}^{-1}$ protein $(2.4 \mu \mathrm{M} \alpha-\mathrm{KB})$ and Bacillus aerius gave $1.8 \mu \mathrm{M} \alpha-\mathrm{KB} \mathrm{h}^{-1} \mathrm{mg}^{-1}$ protein (Fig. 6). Consequently, the color depth of the two bacterial cultures was visibly darker compared with that of the non-inoculated samples.

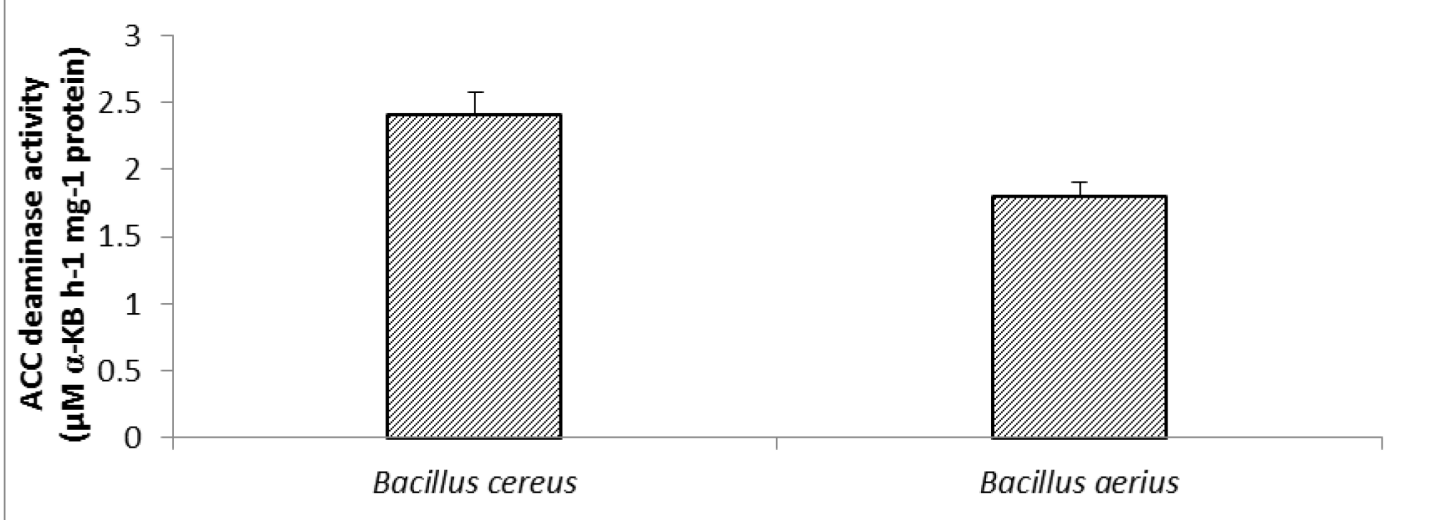

Figure 6. ACC deaminase activity of each ACC-utilizing bacterial isolate measured by the 2,4dinitrophenylhydrazine assay for $\alpha$-ketobutyrate $\mathrm{mg}$ protein $^{-1} \mathrm{~h}^{-1}$ after induction in the DF-ACC medium for $24 \mathrm{~h}$. Each data point represents the mean from triplicate determinations and the error bar represents the standard error.

3.8. Interactive effect of irrigation with different concentrations of $\mathrm{NaCl}$ and inoculation with bacterial strains on growth and chemical composition of Safflower plant

A greenhouse pot experiment was conducted in Botany Department, Faculty of Science, Fayoum University, during the winter season (December 2016) to investigate the effect of salinity alone or in combination with inoculation with Bacillus cereus, Bacillus aerius individually or combination of them on growth and some metabolic activities of Safflower.

\subsection{Growth criteria}

Changes in growth criteria (fresh and dry matter) of Safflower obtained from seeds inoculated with bacterial strains $B$. cereus, B. aerius or $B$. cereus $+B$. aerius and followed by treatment with four concentrations (i.e $0,100,200$ or $300 \mathrm{Mm}$ ) of $\mathrm{NaCl}$ are shown in Fig. 7. Fresh and dry matter of Safflower seedlings were decreased gradually with increasing $\mathrm{NaCl}$ level compared to the control (water). These parameters showed significant increases; 50.5 and $85.0 \%$, and 101.5 and $119.7 \%$ by inoculation with bacterial strains $B$. cereus $+B$. aerius and B.cereus, respectively. These parameters exhibited no significant differences with $B$. aerius when compared with control.

Under $100 \mathrm{mM} \mathrm{NaCl}$, both $B$. cereus and B. cereus $+B$. aerius conferred a significant increase in both growth criteria. These increases were 15.2 and $32.9 \%$, and 43.4 and $115.6 \%$ for the fresh and dry matter, respectively compared to the control. In contrast, $B$. aerius failed to induce seedling growth of Safflower, which reduced significantly compared to the control. Under $200 \mathrm{mM} \mathrm{NaCl}$, both $B$. cereus and B. cereus $+B$. aerius conferred the same growth criteria values; however, with $B$. aerius growth criteria were further reduced compared to control. Under stress conditions of $300 \mathrm{mM} \mathrm{NaCl}$, all bacterial strains failed to equal the growth parameters with the control. 


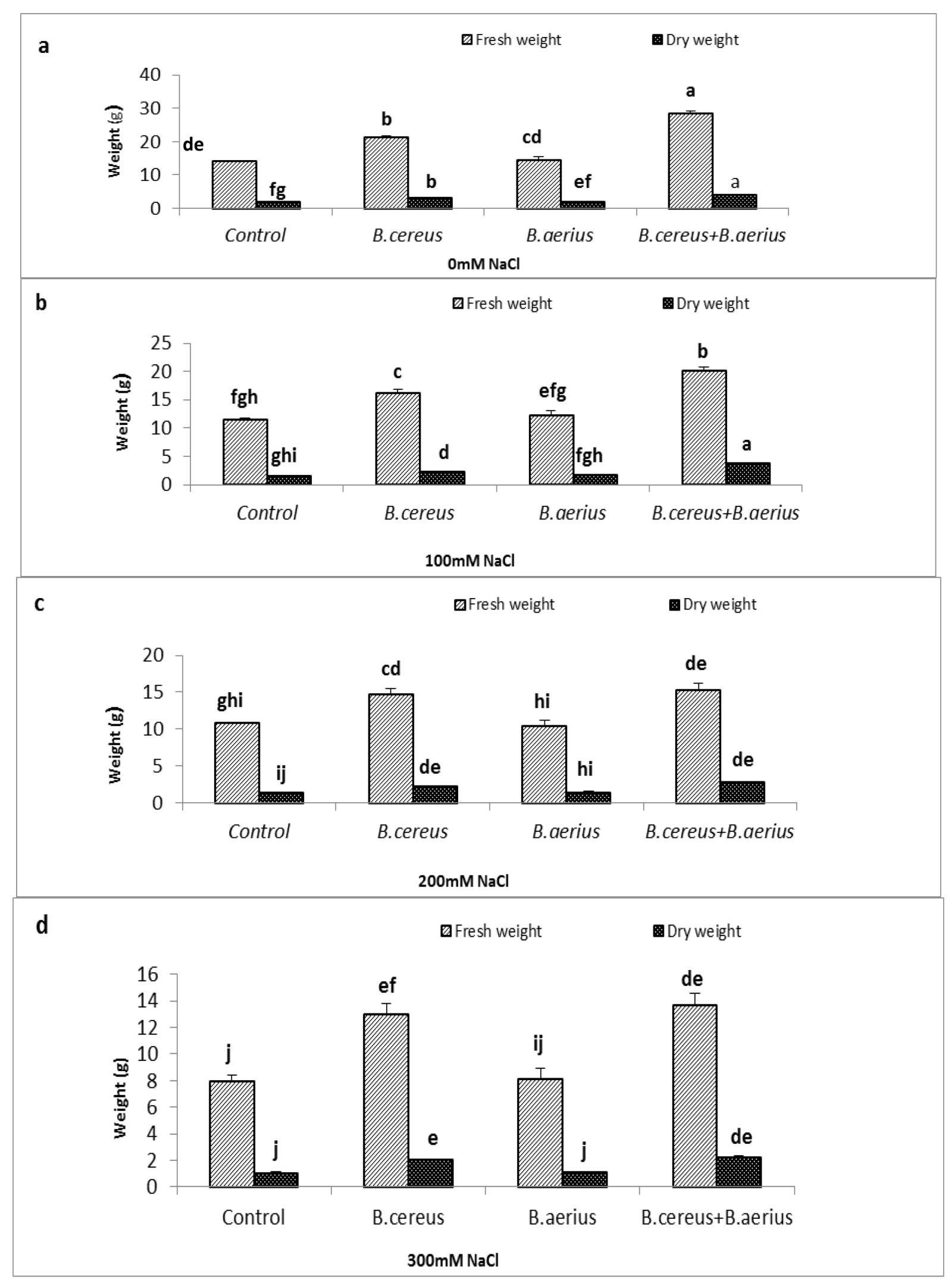

Figure 7. Effect of $\mathrm{NaCl}$ on fresh and dry weight of of 30-days-old Safflower seedlings inoculated with Bacillus cereus and Bacillus aerius under (a) $0 \mathrm{mM} \mathrm{NaCl}$, (b) $100 \mathrm{mM} \mathrm{NaCl}$, (c) $200 \mathrm{mM}$ $\mathrm{NaCl}$ and (d) $300 \mathrm{mM} \mathrm{NaCl}$. Data are the mean $\pm \mathrm{SE}$. 


\subsection{Enzyme activities}

Changes in activities of catalase, glutathione reductase and ascorbate peroxidase of Safflower seedling in response to inoculation with $B$. cereus, B. aerius or $B$. cereus $+B$. aerius followed by treatment with different levels of salinity are presented in Fig. 8. The results showed that the activity of CAT in Safflower seedling significantly increased with increasing $\mathrm{NaCl}$ levels. However, the activity of GR\&ApX significantly decreased. Under $100 \mathrm{mM} \mathrm{NaCl}$, B. cereus or B. cereus $+B$. aerius conferred significant increases in both CAT\&APX by $223.8 \& 278.6 \%$ or $29.14 \& 87.4 \%$ respectively, while $B$. aerius increased CAT by $424.8 \%$ and decreased CAT activity by $23.1 \%$. On the other hand, inoculation with $B$. aerius or $B$. cereus $+B$. aerius significantly decreased GR activity by 12.5 or $35.5 \%$ respectively as soon as $B$. cereus highly affected GR activity compared with the control. Under $200 \mathrm{mM} \mathrm{NaCl}, B$. cereus or B. aerius significantly increased CAT, GR and ApX by $304.8,9.38 \& 64.2 \%$ and $471.4,6.25 \& 90.4 \%$, respectively, while inoculation with $B$. cereus $+B$. aerius induced increases in CAT and ApX by $488.1 \& 52.4 \%$ respectively, while GR activity was decreased by $12.5 \%$. Under the stress condition of $300 \mathrm{mM} \mathrm{NaCl}$, all bacterial strains (B. cereus, B. aerius or B. cereus + B. aerius) showed highly significant induction in CAT, GR and APX activities comparing to control.

\subsection{Non- enzymatic antioxidants (glutathione and ascorbic acid)}

The role played by inoculation with bacterial strains (B. cereus, B. aerius or B. cereus $+B$. aerius) in modifying salt stress-induced changes in the biosynthesis of glutathione and ascorbic acid is presented in Fig. 9. The glutathione and ascorbic acid contents of Safflower significantly decreased with rising salinization levels. Inoculation with bacterial strains $B$. cereus, $B$. aerius or $B$. cereus $+B$. aerius increased the contents of glutathione and ascorbic acid in Safflower seedlings with increasing treatment with $\mathrm{NaCl}$ level. Highest significant increase was in GsH\&AsA content observed with $300 \mathrm{mM} \mathrm{NaCl}$ treatment and all bacterial strains; B. cereus, B. aerius or B. cereus $+B$. aerius by $572.1,330.4 \& 488.2$ and $68.5,95.7 \& 99.3 \%$, respectively. 


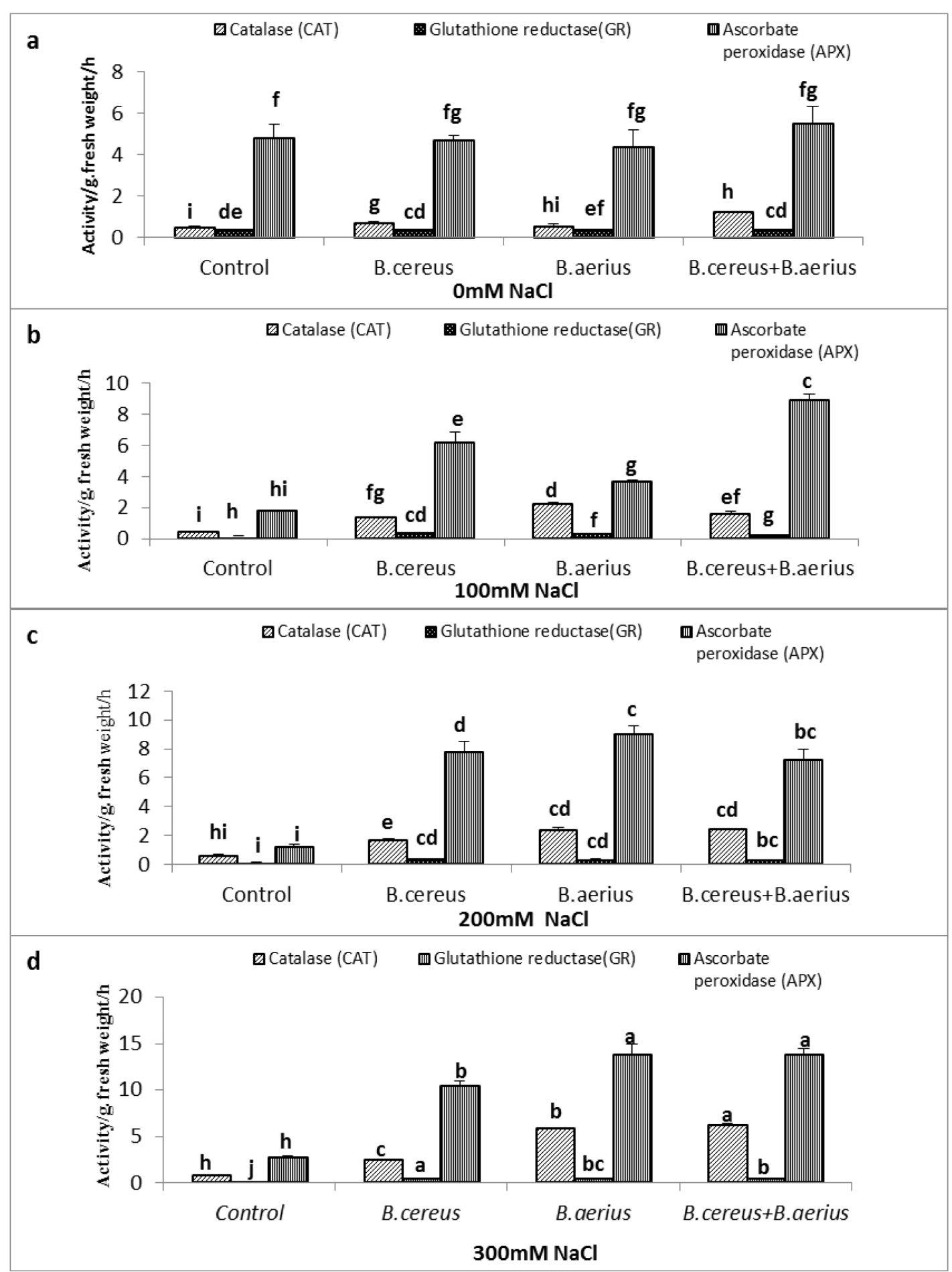

Figure 8. Effect of $\mathrm{NaCl}$ on Enzymatic activity of catalase (CAT), Glutathione reductase (GR), and Ascorbate peroxidase (ApX) of 30-days-old Safflower seedlings inoculated with Bacillus cereus and Bacillus aerius under (a) $0 \mathrm{mM} \mathrm{NaCl}$, (b) $100 \mathrm{mM} \mathrm{NaCl}$, (c) $200 \mathrm{mM} \mathrm{NaCl}$ and (d) $300 \mathrm{mM}$ $\mathrm{NaCl}$. Data are the mean $\pm \mathrm{SE}$. 


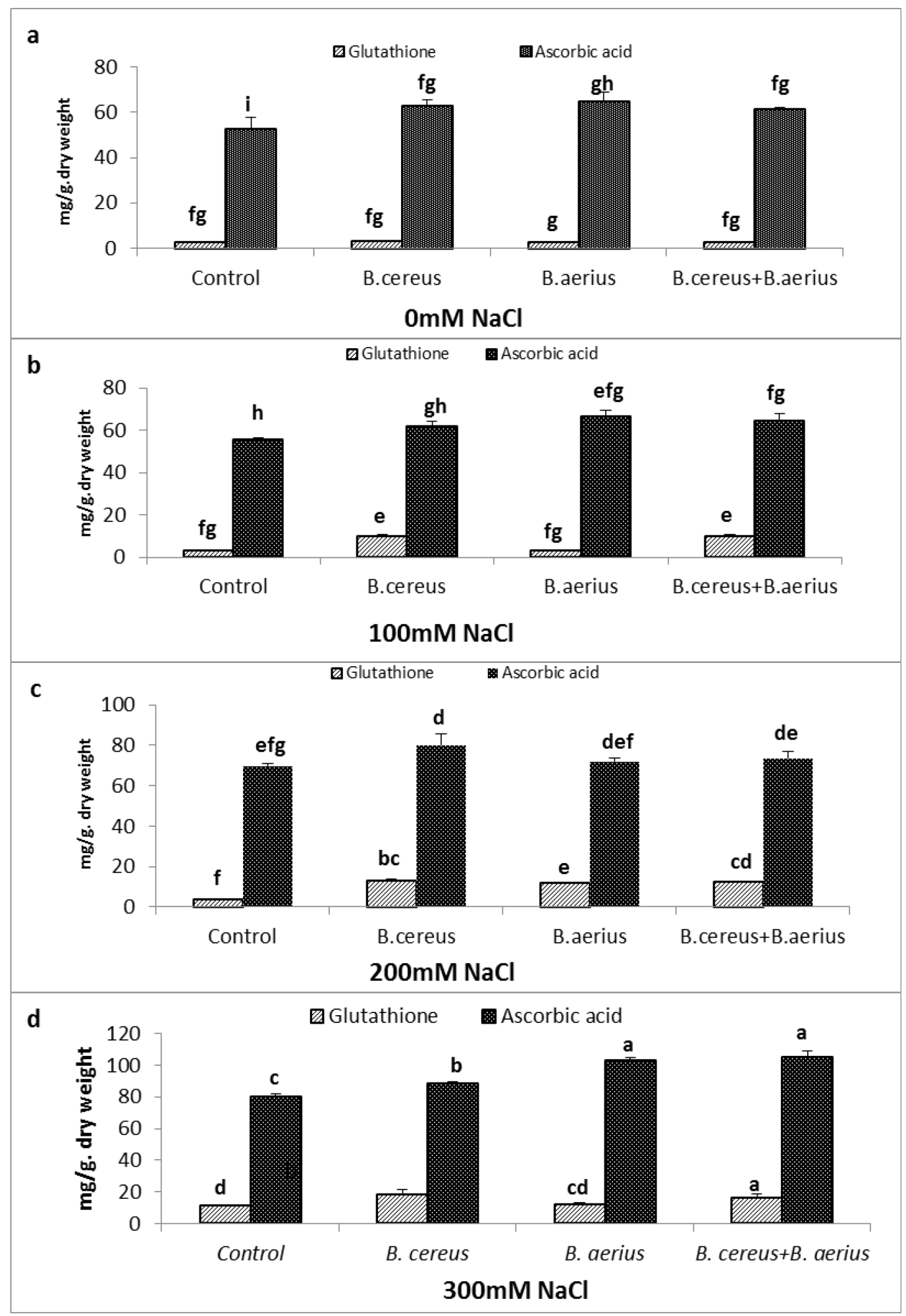

Figure 9. Effect of $\mathrm{NaCl}$ on Non-enzymatic antioxidants, glutathione (GsH) and ascorbate AsA) of 30-days-old Safflower seedlings inoculated with Bacillus cereus and Bacillus aerius under (a) $0 \mathrm{mM} \mathrm{NaCl}$, (b) $100 \mathrm{mM} \mathrm{NaCl}$, (c) $200 \mathrm{mM} \mathrm{NaCl}$ and (d) $300 \mathrm{mM} \mathrm{NaCl}$. Data are the mean \pm SE.

\section{Discussion}

Most environmental stresses are thought to result in overproduction of reactive oxygen species (ROS) in plant causing oxidative stress [38, 39, 40]. Evidence suggests that salinity cause oxidative damage through the excessive generation of oxygen radicals such as singlet oxygen $\left({ }^{1} \mathrm{O}_{2}\right)$, superoxide $\left(\mathrm{O}_{2}^{-{ }^{-}}\right)$, hydrogen peroxide $\left(\mathrm{H}_{2} \mathrm{O}_{2}\right)$ and hydroxyl radicals $\left(\mathrm{OH}^{-}\right)$[41]. Or is associated 
with oxidative stress through altering antioxidant molecules levels in plants [38, 39, 41]. Excess of ROS triggers phytotoxic reactions such as lipid peroxidation, protein degradation and DNA mutation $[42,43]$.

A wide range of adaptations strategies is required to overcome salinity stress. However, such strategies being long drawn and cost-intensive, there is a need to develop simple and low-cost methods for salinity stress alleviation management, which can be used on a short-term basis.

Microorganisms could play an important role in this respect; they can synthesize compatible solutes, produce plant growth promoting hormones, bio-control potential, and their interaction with crop plants [12]. Endophytic bacteria are of considerable interest due to their potential role in alleviating abiotic stress conditions [44].

It has been confirmed in recent years that plant growth promoting endophytes (PGPEs) have the ability to colonize host plant's internal tissues and further build a beneficial symbiotic association with their host plants to enhance host plant growth stress tolerance [45]. In this study, we have isolated two strains of endophytic bacteria from safflower. These strains were Bacillus cereus and Bacillus aerius, which were selected and systematically investigated for plant growth promoting (PGP) properties, the ability of internal tissues colonizing, and their ability to tolerate salinity. It has also been confirmed that the endophytic bacteria tested can successfully colonize in vivo the host plants and cause stimulation in plant growth criteria and synthesis of some biochemical compounds [46].

The data obtained in this investigation is clearly demonstrated that $\mathrm{NaCl}$, when applied at all levels of $\mathrm{NaCl}(100,200$ and300 $\mathrm{Mm} \mathrm{NaCl}$ ), significantly decreased plant growth parameters (fresh-dry matters). In this respect, extensive studies have been conducted concerning the inhibitory effects of salt stress on plant growth using different species and different methods to alleviate its effect $[43,47,41]$. The adverse effect of $\mathrm{NaCl}$ on plant growth has been attributed to changes in osmotic potential resulting from reduced water [48, 49].

Seeds of Safflower inoculated with bacterial strains (Bacillus cereus) and a combination of B. cereus $+B$. aerius increased significantly growth parameters (fresh-dry) weight, PGPEs can stimulate plant growth directly with different and unique mechanisms such as the production of plant hormones, enhancement of nutrient uptake and stress tolerance [50,51]. A particular endophytic bacterium may promote plant growth and development using one or more of these mechanisms at various times during the life cycle of the plant [51]. In this research, each of the endophytic bacteria tested possessed at least two or more properties that were linked to the plant growth promoting activities, including the ability of IAA production, siderophore production, nitrogen fixation, ammonia production, inorganic phosphate solubilization, or ACC deaminase activity. Therefore, the inoculants combined with different endophytic bacteria may possibly possess various PGP properties that can be complementary with each other to offer them an enhanced power to optimally facilitate the growth of a plant by utilization of various mechanisms at different times during the life cycle of host plants.

In recent years, endophytes have been used as one of the practical measurements to alleviate salt stress and improve plant and yield under saline conditions [52, 51, 53]. In addition, in our study, the used bacterial isolates have the ability to achieve systemic tolerance via production of ACC (1-amino cyclopropane-1-carboxylase) deaminase which has the ability to reduce the production of stress hormone ethylene. Antioxidative enzymes are the first response mechanism against environmental stresses. As such, their activity profiles are important in the evaluation of tolerance mechanisms. The results showed a significant decrease in glutathione reductase (GR) and ascorbate peroxidase (APX) in Safflower seedling with increasing NaCl levels, while the activity of CAT was significantly increased. This increase of GSH and AsA synthesis in plant tissues might be a consequence of CAT, APX and GR activity in plant tissues. The first enzyme working founded is superoxide dismutase (SOD) that works on superoxides $\left(\mathrm{O}_{2}{ }^{-{ }^{-}}\right)$to convert them into either $\mathrm{O}_{2}$ or $\mathrm{H}_{2} \mathrm{O}_{2}[54,55]$, conducted that CAT is considered as the primary scavenger in the detoxification of $\mathrm{H}_{2} \mathrm{O}_{2}$ to $\mathrm{H}_{2} \mathrm{O}$ and $\mathrm{O}_{2}$ offers protecting cells against superoxide induced oxidative stress. 
Temporarily, GR and APX activity is involved in the ascorbate-glutathione redox cycle and it has a key role in maintaining the reduced glutathione and ascorbic acid pool during stress.

In our study, the ability of the two Bacillus species to improve the detoxification system was analyzed. It was observed that the content of GR, APX, and CAT was increased by increasing the level of $\mathrm{NaCl}$, in case of single and dual pre-inoculated seeds Fig. 8. These results are in harmony with results that demonstrated by [56] who have stated that the antioxidant enzymes activities of ApX, GR, and CAT were increased by a particular inoculation of Sulla provenances by Bacillus sp., Pseudomonas sp. or a combination of them. A correlation between non-enzymatic antioxidant capacity and $\mathrm{NaCl}$ tolerance has been demonstrated in several plants [57, 47, 41].

The present investigation was there for undertaken to study the effect of $\mathrm{NaCl}$ on AsA and GSH contents alone or with inoculation with bacterial strains. Our results showed that bacterial inoculations play an important role in stimulation of non-enzymatic antioxidants content in Safflower seedlings Fig. 8; these results were evident on the effective role of Bacillus cereus and Bacillus aerius in ascorbate-glutathione redox cycle enhancement. This finding is in accordance with the findings of [58]. This may be attributed to that AsA is an important antioxidant that reacts not only with $\mathrm{H}_{2} \mathrm{O}_{2}$ but also with $\mathrm{O}_{2-}, \mathrm{OH}^{-}$and lipid hydro- peroxidases. In addition, it has been implicated in several types of biological activities in plants such as an enzyme co-factor, an antioxidant, and a donor/acceptor in electron transport at the plasma membrane or in the chloroplasts, all of which are related to oxidative stresses resistance [59]. "Halliwell-Asada" pathway which was found in chloroplasts indicates that APX uses AsA and oxidizes it to monodehydroascorbate (MDA). The MDA may give rise to dehydroascorbate (DHA). Both MDA and DHA will then be reduced to regenerate the ascorbate pool [60]. This type of scavenging is to occur near PSI, thereby minimizing the risk of escape and reaction of ROS with each other. Because there dox-potential of AsA/MDA pair $(280 \mathrm{mv})$ is lower than that of most of the bio-radicals, so AsA is also known to function as the "terminal antioxidant" [61]. It was suggested that there may be links between photosynthesis and the AsA pool size; thus, explaining the bio-synthesis of AsA from hexose phosphate and its involvement in protection against photo-oxidative stress [62]. [63] It was concluded that glutathione is a non-protein sulfur-containing tripeptide, which acts as storage and is the transporting form of reduced sulfur. GSH function as an antioxidant received much more attention from the researchers. A central nucleophilic cysteine residue is responsible for the high reductive potential of GSH. It scavenges cytotoxic $\mathrm{H}_{2} \mathrm{O}_{2}$ and reacts non-enzymatically with other ROS, including singlet oxygen, superoxide, and hydroxyl radicals.

\section{Conclusions}

In a conclusion, our findings reported that the co-inoculation of the two selected endophytic bacteria strains were successfully isolated from Safflower seedlings significantly alleviated the harmful effects of salt stress, promoted plant growth and biomass yield. Each of the bacterial strains tested showed at least two or more PGP properties including the ability of IAA production and ACC deaminase activity. Thus, these evaluations suggest a potential utilization of these beneficial bacterial endophytes as promising candidates for bio-inoculants, which play role in the alleviation of the harmful effect of salt stress and; thus, can greatly be reported in the inoculants with the dual strains B. cereus + B. aerius.

\section{Conflict of Interest}

The authors declare that there is no conflict of interest. 


\section{References}

[1] B.R. Glick, D.M. Penrose, J. Li, A model for the lowering of plant ethylene concentrations by plant growth promoting bacteria, J. Theor. Biol. 190 (1998) 63-68.

[2] S.H. Nia et al., Yield and yield components of wheat as affected by salinity and inoculation with Azospirillum strains from saline or non-saline soil, J. Saudi Soc. Agric. Sci. 11 (2012) 113-121.

[3] D. Ramadoss et al., Mitigation of salt stress in wheat seedlings by halotolerant bacteria isolated from saline habitats, Springer Plus. 2(6) (2013) 1-7.

[4] M.R. Swain, R.C. Ray, C.S. Nautiyal, Biocontrol efficacy of Bacillus subtilis strains isolated from cow dung against postharvest yam (Dioscorea rotundata L.) pathogens. Curr. Microbiol. 57 (2008) 407-411.

[5] R.K. Gothwal et al., Screening of nitrogen fixers from rhizospheric bacterial strains associated with important desert plants, Appl. Ecol. Environ. Res. 6 (2007) 101-109.

[6] U. Iqbal et al., Effect of zinc-phosphate-solubilizing bacterial isolateson growth of Vigna radiate, Annals of Microbiology. 60(2) (2010) 243-248.

[7] S.M. Kang et al., Gibberellin production and phosphate solubilization by newly isolated strains of Acinetobacter calcoaceticus and its effect on plant growth, Biotechnol. Lett. 31 (2009) 277-281.

[8] M. Madhaiyan et al., Regulation of ethylene levels in canola (Brassica campestris) by 1aminocyclopropane-1-carboxylate deaminase-containing Methylobacterium fujisawaense, Planta. 224 (2006) 268-278.

[9] A.Z. Zahir et al., Comparative effectiveness of Pseudomonas and Serratia sp. containing ACC-deaminase for improving growth and yield of wheat (Triticum aestivum L.) under saltstressed conditions, Arch Microbiol. 191 (2009) 415-424.

[10] M. Grover et al., Role of microorganisms in adaptation of agriculture crops to abiotic stresses, World J. Microbiol. Biotechnol. 27 (2011) 1231-1240.

[11] M.R. Foolad, Recent advances in genetics of salt tolerance in tomato, Plant Cell Tiss. 76 (2004) 101-119.

[12] P. Shrivastava, R. Kuma, Soil salinity: A serious environmental issue and plant growth promoting bacteria as one of the tools for its alleviation, Saudi J. Biolog. Sci. 22 (2015) 123131.

[13] J. Cuartero et al., Increasing salt tolerance in tomato, J. Exp. Bot. 57 (2006) 1045-1058.

[14] Z. Cheng, E. Park, B.R. Glick, 1-Aminocyclopropane-1-carboxylate deaminase from Pseudomonas putida UW4 facilitates the growth of canola in the presence of salt, Can. J. Microbiol. 53(7) (2007) 912-918.

[15] Y.L. Li et al., Substitution of wheat dried distillers grains with solubles for barley grain or barley silage in feedlot cattle diets: Intake, digestibility, and ruminal fermentation, J. Anim. Sci. 89(820) (2011) 2491-2501.

[16] B.R. Glick, Promotion of plant growth by bacterial ACC deaminase, Crit. Rev. Plant Sci. 26 (2007) 227-242.

[17] N.Hontzeas,S. S. Saleh,B. R. Glick, Changes in gene expression in canola roots induced by ACC-deaminase-containing plant-growth-promoting bacteria, Molecular Plant Microbe Interactions. 17 (2004) 865-871. 
[18] S. Mayak, T. Tirosh, B.R. Glick, Plant growth-promoting bacteria confer resistance in tomato plants to salt stress. Plant Physiol. Biochem.42 (2004) 565-572.

[19] P. Sharma et al., Reactive oxygen species, oxidative damage, and antioxidative defense mechanism in plants under stressful conditions, J. Bot. 26 (2012).

[20] M.E. Younis, S.M.N. Tourky, Influence of salinity and adaptive compounds on oxidative stress and antioxidant system in broad bean cultivars contrasting in salt tolerance, Plant Know. J. 4(1) (2015) 25-32.

[21] A.K. Parida, A.B. Das, Salt tolerance and salinity effect on plants - a review, Ecotoxicol. Environ. Saf. 60 (2005) 324-349.

[22] M.E. Younis, M.N.A. Hasaneen, A.M.S. Kazamel, Plant growth metabolism and adaptation in relation to stress conditions. XXVI. Exogenously applied ascorbic acid ameliorates detrimental effects of $\mathrm{NaCl}$ and mannitol stress in Vicia faba seedlings, Protoplasma. 239 (2010) 39-48.

[23] D.M. Kasote, S.S. Katyare, M.V. Hegde, H. Bae, Significance of antioxidant potential of plants and its relevance to the rapeutic applications, Int. J. Biol. Sci. 11(8) (2015) 982-991.

[24] S. Gagne et al., Xylem-residing bacteria in alfalfa roots, Can. J. Microbiol. 33 (1987) 9961000 .

[25] S.R.S. Janarthine et al., Endophytic bacteria isolated from the pneumatophores of Avicennia marina, Afr. J. Microbiol. Res. 5(26) (2011) 4455-4466.

[26] B.K. Singh et al., Biodegradation of chlorpyrifos by Enterobacter strain B-14 and its use in bioremediation of contaminated soils, Appl. Environ. Microbiol. 70 (2004) 4855-4863.

[27] M.M. Bradford, A rapid and sensitive method for the quantition of microgram quantities of protein utilizing the principle of protein-dye binding, Anal. Biochem. 72 (1976) 248-254.

[28] E. Salkowski, Ueber das Verhalten der Skatolcarbonsa"ure im Organismus, Z. Physiol. Chem. 9 (1885) 23-33.

[29] J. Sambrook, E. Fritsch, T. Maniatis: Molecular Cloning: A Laboratory Manual, 2nd Ed., Cold Spring Harbor Laboratory Press, Cold Spring Harbor, N.Y, 1989.

[30] D. M.Penrose, B. R.Glick, Methods for isolating and characterizing ACC deaminasecontaining plant growth promoting rhizobacteria, Plant. Physiol. 118 (2003) 10-15.

[31] J. Sambrook, D.W. Russell, Media. In Molecular Cloning: A Laboratory Manual, 3rd Ed., New York: Cold Spring Harbor Laboratory Press, 2001, Appendix 2, pp. A2.2.

[32] A.M. Essa, Effect of continuous mercury stress on mercury reducing community of some characterized bacterial strains, Afr. J. Microbiol. Res. 6(6) (2012) 1255-1261.

[33] M. Honma, T. Shimomura, Metabolism of 1-aminocyclopropane-1-carboxylic acid, Agri. Biol. Chem .42 (1978) 1825-1831.

[34] B. Fu et al., Isolation and identification of hydrogen-oxidizing bacteria producing 1aminocyclopropane-1-carboxylate deaminase and the determination of enzymatic activity, Acta Microbiol Sin. 49 (2009) 395-399.

[35] T. Keller, H. Schwager, Air pollution and ascorbic acid. Eur. J. Plant Pathol. 7 (1977) 338350.

[36] M.S. Moron, J.W. Depierre, B. Mannervik, Levels of glutathione, glutathione reductase and glutathione-S-transferase activities in rat lung and liver, Biochim. Biophys. Acta. 582 (1979) 67-78. 
[37] R. Aroca, J.J. Irigoyen, M. Sánchez-Díaz, Drought enhances maize chilling tolerance. II. Photosynthetic traits and protective mechanisms against oxidative stress, Physiol. Plant. 117 (2003) 540-549.

[38] H. Aebi, Catalase in vitro, Methods Enzymol. 105 (1984) 121-126.

[39] K. Amako, G.X. Chen, K. Asada, Separate assays specific for ascorbate peroxidase and guaiacol peroxidase and for the chloroplastic and cytosolic isozymes of ascorbate peroxidase in plants, Plant Cell Physiol. 35 (1994) 497-504.

[40] I. Carlberg, B. Mannervik, Glutathione reductase, Methods Enzymol. 113 (1985) 484-489.

[41] T. Karuppanapandian et al., Reactive oxygen species in plants: their generation, signal transduction, and scavenging mechanisms, AJCS. 5(6) (2011) 709-725.

[42] P. Sharma et al., Reactive oxygen species, oxidative damage, and antioxidative defense mechanism in plants under stressful conditions, J. Botany. (2012) 1-27.

[43] M.M. Rady, A.K. Hemida, Sequenced application of ascorbate-proline-glutathione improves salt tolerance in maize seedlings, Ecotoxicol. Environ. Safety. 133 (2016) 252-259.

[44] A. K. Hemida et al., Integrated effect of potassium humate and $\alpha$-tocopherol applications on soil characteristics and performance of Phaseolus vulgaris plants grown on a saline soil, Archives Agro Soil Sci. 63(11) (2017 )1556-1571.

[45] T. Balakhnina et al., Oxidative damage and antioxidant defense system in leaves of Vicia faba major L. cv. Barton during soil flooding and subsequent drainage, Plant Soil. 327 (2010) 293301.

[46] A.K. Hemida et al., Ameliorative role of some antioxidant compounds on physiological parameters and antioxidants response of wheat (Triticum aestivum L.) seedlings under salinity stress, Life Sci J. 11(7) (2014) 324-342.

[47] G. Brader et al., Metabolic potential of endophytic bacteria, Curr. Opin. Biotechnol. 27 (2014) 30-37.

[48] D. Saravanakumar, R. Samiyappan, ACC deaminase from Pseudomonas Xuorescens mediated saline resistance in groundnut (Arachis hypogea) plants, J. Appl. Microbiol. 102 (2007) 1283-1292.

[49] S. Islam et al., Isolation and identification of plant growth promoting rhizobacteria from cucumber rhizosphere and their effect on plant growth promotion and disease suppression, Front. Microbiol. 6 (2015) 1360.

[50] M. Atak et al., Effects of $\mathrm{NaCl}$ on the germination, seedling growth and water uptake of triticale, Turk. J. Agric. 30 (2006) 39-47.

[51] S.A.R. Mousavi et al., Glutamate receptor-like genes mediate leaf-to-leaf wound signalling, Nature. 500 (2013) 422-426

[52] G. Santoyo et al., Plant growth-promoting bacterial endophytes, Microbiol. Res. 183 (2016) 92-99.

[53] X. Li et al., The endophytic bacteria isolated from elephant grass (Pennisetum purpureum Schumach) promote plant growth and enhance salt Tolerance of Hybrid Pennisetum, Biotechnol Biofuels. 9 (2016) 190.

[54] S. Ali, T.C. Charles, B.R. Glick, Amelioration of high salinity stress damage by plant growthpromoting bacterial endophytes that contain ACC deaminase, Plant Physiol. Biochem. 80 (2014) 160-167. 
[55] F. Orhan, Alleviation of salt stress by halotolerant and halophilic plant growth-promoting bacteria in wheat (Triticum aestivum) Brazil, J. Microbiol. 47 (2016) 621-627.

[56] Y. Sheng et al., Superoxide Dismutases and Superoxide Reductases, Chem. Rev. 114(7) (2014) 3854-3918.

[57] M. Farooq et al., Plant drought stress: effects, mechanisms and management, Agron. Sustain. Dev. 29 (2009) 185-212.

[58] R. Hidri et al., Impact of microbial inoculation on biomass accumulation by Sulla carnosa provenances, and in regulating nutrition, physiological and antioxidant activities of this species under non-saline and saline conditions, J. Plant. Physiol. 201 (2016) 28-41.

[59] M. Sklodowska et al., Tocopherol content and enzymatic antioxidant activities in chloroplasts from NaCl-stressed tomato plants, Acta Physiol. Plant. 31 (2009) 393-400.

[60] M.M. Rady et al., Exogenous a-tocopherol has a beneficial effect on Glycine max (L.) plants irrigated with diluted sea water, J. Hortic. Sci. Biotechnol. 90 (2015) 195-202.

[61] R. Panwar et al., Conservative versus liberal oxygenation targets for mechanically ventilated patients. A pilot multicenter randomized controlled trial, Am. J. Respir. Crit. Care Med. 193(1) (2016) 43-51.

[62] P.I. Conklin, Recent advances in the role and biosynthesis of ascorbic acid in plants, Plant Cell Environ. 24 (2001) 383-394.

[63] C.H. Foyer, G. Noctor, Oxygen processing in photosynthesis: regulation and signaling, New Phytol. 146 (2000) 359-388. 